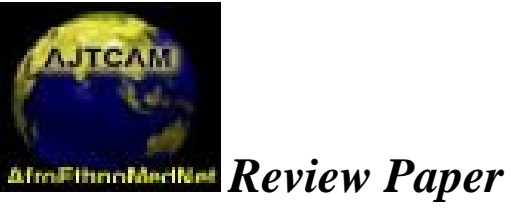

Afr. J. Infect. Diseases

www.africanethnomedicines.net

ISSN: 2006-0165@2009

\title{
A SYSTEMATIC REVIEW OF THE EPIDEMIOLOGY OF MANSONELLIASIS
}

\author{
Barbara L. Downes and Kathryn H. Jacobsen \\ Department of Global \& Community Health at George Mason University \\ (Fairfax, Virginia, USA). \\ E-mail: kjacobse@gmu.edu
}

\begin{abstract}
Although infection with any of the three types of Mansonella species that affect humans is often asymptomatic, a large portion of the world's population is at risk of this vectorborne filarial nematode infection. No previous global review of the epidemiology of mansonelliasis has been conducted. A systematic review of the literature was conducted. Original research articles that provided population-based mansonelliasis prevalence rates were identified by searching the PubMed database using pre-defined eligibility criteria. Data from each of the forty-six included studies were extracted and compared. Mansonelliasis is a common infection in some parts of west and central Africa and Latin America, with significant variation in prevalence rates over small geographic spaces. The risk of infection increases with age and may be higher in males than females. Despite many similarities, the three agents that cause mansonelliasis have distinct biological, clinical, and epidemiological characteristics. Knowledge about mansonelliasis is important for making differential diagnoses, identifying the possible risks of co-infection with multiple filariases, and addressing the concerns of at-risk populations.
\end{abstract}

Keywords: mansonelliasis; filariasis; mansonella; epidemiology

\section{Introduction}

Mansonelliasis is one of several filarial nematode infections for which humans are the definitive host. This puts it in the same category as several parasitic infections of importance to global public health, including onchocerciasis, lymphatic filariasis, dracunculiasis, and loiasis. The three agents that cause mansonelliasis Mansonella perstans, M. streptocerca, and M. ozzardi - vary in features such as anatomy and periodicity, the vectors that transmit the agent to humans, the clinical signs and symptoms they cause, and the world regions where they are endemic. While some of these major filarial infections have garnered international attention onchocerciasis (river blindness) (Gardon et al., 1997) and dracunculiasis (Guinea worm) (Barry, 2007; Cairncross et al., 2002) have been the focus of global eradication efforts - mansonelliasis has been neglected.

This paper is the first systematic global review of the epidemiologic literature on all three forms of mansonelliasis. A systematic search strategy was used to identify 46 original scientific articles of the prevalence of mansonelliasis. These publications report on studies from 18 countries in Africa and Latin America. After providing a brief background on the key features of each of the three types of mansonelliasis, this paper provides a comparison of the epidemiology of these infections, with an emphasis on at-risk populations and geographic regions. Up-to-date epidemiological information is essential for making differential diagnoses, planning public health interventions, and advancing research in the field.

\section{Background on Mansonelliasis Agent and Vector Characteristics}

Three types of Mansonella, which are filarial nematodes (roundworms), are known to infect humans: M. perstans (formerly Dipetalonema perstans), M. streptocerca (formerly Dipetalonema streptocerca), and $M$. 
ozzardi (CDC, 2008; Garcia, 2007; Heymann, 2004). The life cycles for all three species are similar, involving development in both an insect vector and a primate host. Culicoides (biting midges) are effective vectors for all three species; Simulium (black flies) are a vector only for M. ozzardi (Shelley, 2001). Both vectors require blood meals in order for their eggs to mature (Black et al., 2004). When a female arthropod takes a blood meal from an infected host, microfilariae are ingested by the insect, penetrate the insect's gut and go through several maturation stages in the thoracic muscles over 6 to 12 days before migrating to the head and proboscis, where they can be transferred to a primate through an insect bite (Black et al., 2004; CDC, 2008). Humans are the only known vertebrate host for $M$. ozzardi; other primates can serve as host to $M$. perstans and M. streptocerca (Garcia, 2007). After the vector deposits filarial larvae onto the skin of the host, the larvae penetrate into the bite wound, mature into adult worms, and then the adult female worms produce unsheathed microfilariae that circulate in the blood (all three species) or diffuse into the skin (M. streptocerca only) of the primate host (Black, 2004; CDC, 2008; Garcia, 2007). All three species have non-periodic microfilariae that circulate in peripheral blood throughout the day and night (Garcia, 2007; Mommers et al., 1994; Service, 2004). The size of the adult worms varies by species, and microfilariae differ in the shape of the tail and the distribution of body nuclei. Key differences between these species are highlighted on Table 1.

\section{Clinical Characteristics}

Table 1 highlights key differences in signs and symptoms, diagnosis, and treatment between the three species. Infection with any of the three is often asymptomatic. Symptoms that do occur are related to the preferred location of the agent: $M$. perstans are typically found in body cavities, $M$. streptocerca in dermal and subcutaneous tissue, and M. ozzardi in subcutaneous tissues (Garcia, 2007; Heymann, 2004). Symptoms of infection with $M$. perstans may include pectoral and chest pains, periodic dizziness, joint and back pain, and ocular symptoms (Anosike et al., 2005b; Bregani et al., 2006; Bregani et al., 2007). Infection with $M$. streptocerca, which is found under the skin, is associated with cutaenous edema (build-up of fluid in the skin), thickening of the skin, formation of hypopigmented macules (flat blotches) and papules (raised bumps), and pruritus (itchiness) (Heymann, 2004; Fischer et al., 1997). M. ozzardi may cause symptoms that include skin rashes, headaches, fever, pruritus, lymphedema (swelling of the arms or legs), and joint pain (CDC, 2008; Garcia, 2007).

\section{Diagnosis and Treatment}

Diagnosis and treatment also vary by species (Table 1). Blood smears that look for microfilariae are the easiest way to diagnose M. perstans and M. ozzardi (CDC, 2008). M. streptocerca microfilariae do not circulate in the blood, so it is necessary to take a skin snip (CDC, 2008). Care must be taken to differentiate mansonelliasis from onchocerciasis or other filarial infections (Fischer et al., 1997). Treatment must be specific to the infective agent. M. perstans is most effectively treated with mebendazole; ivermectin is not effective against M. perstans, but is the drug of choice for treating M. ozzardi (Garcia, 2007; Heymann, 2004). Both diethylcarbamazine (DEC) and ivermectin have been used to treat $M$. streptocerca infection (Garcia, 2007).

\section{Methods}

Systematic reviews of the literature minimize the selection bias that may occur in narrative reviews that select articles by hand rather than by using a strict set of inclusion criteria. This methodical approach yields a valid and comparable set of research articles which together can reveal trends and gaps in the published research literature.

A systematic review of original research articles focusing on the prevalence of mansonelliasis was conducted using PubMed, a database from the U.S. National Institutes of Health that searches all MEDLINE citations along with several other databases and older publications (Figure 1). A search for "mansonelliasis" yielded 173 results. The abstracts and/or full-texts of these articles were screened for eligibility. Of the 173 articles, 127 were ineligible: 30 that included only individuals with mansonelliasis and did not provide any population-based statistics, 26 that examined the vectors of infection rather than the human hosts, 22 that reported solely on laboratory techniques and diagnostic methods, 18 that evaluated treatment for mansonelliasis, 16 that focused on a disease other than mansonelliasis and only mentioned mansonelliasis in the commentary, and 15 additional articles that did not report population-based prevalence rates.

All of the 46 remaining articles were located and read, and information about the study country, study years, sample size, age range of participants, and prevalence was recorded. All languages were eligible for inclusion, and the 46 eligible articles were in English (39), Spanish (3), Portuguese (3), and French (1). 
Table 1: Agent characteristics [CDC, 2004; Garcia, 2007; Heymann, 2004].

\begin{tabular}{|c|c|c|c|}
\hline Agent & Mansonella perstans & Mansonella streptocerca & Mansonella ozzardi \\
\hline Adult Size & $4-8 \mathrm{~cm} \times 0.06 \mathrm{~mm}$ & $2 \mathrm{~cm} \times 0.01 \mathrm{~mm}$ & $3-5 \mathrm{~cm} \times 0.07-0.15 \mathrm{~mm}$ \\
\hline $\begin{array}{l}\text { Microfilarial } \\
\text { Characteristics }\end{array}$ & $\begin{array}{l}100-200 \mu \mathrm{m} \times 5 \mu \mathrm{m} ; \\
\text { blunt rounded tail; body } \\
\text { nuclei extend to tip of tail }\end{array}$ & $\begin{array}{l}180-240 \mu \mathrm{m} \times 2.5-5 \mu \mathrm{m} ; \\
\text { curved hooked "Shepherd's } \\
\text { crook" tail; body nuclei } \\
\text { extend to tip of tail }\end{array}$ & $\begin{array}{l}170-240 \mu \mathrm{m} \times 3-4 \mu \mathrm{m} ; \\
\text { long thin pointed tail; body } \\
\text { nuclei do not extend to tip of } \\
\text { tail }\end{array}$ \\
\hline Vector & $\begin{array}{l}\text { Culicoides spp. } \\
\text { (biting midges) }\end{array}$ & $\begin{array}{l}\text { Culicoides spp. } \\
\text { (biting midges) }\end{array}$ & $\begin{array}{l}\text { Culicoides spp. } \\
\text { (biting midges) and } \\
\text { Simulium spp. (blackflies) }\end{array}$ \\
\hline Hosts & $\begin{array}{l}\text { humans, gorillas, and } \\
\text { monkeys }\end{array}$ & humans and monkeys & humans \\
\hline $\begin{array}{l}\text { Signs / } \\
\text { Symptoms }\end{array}$ & usually asymptomatic & $\begin{array}{l}\text { often asymptomatic; may } \\
\text { cause chronic pruritus } \\
\text { (itchiness) and thick papules } \\
\text { on skin }\end{array}$ & $\begin{array}{l}\text { often asymptomatic; may } \\
\text { cause malaise }\end{array}$ \\
\hline $\begin{array}{l}\text { Common Adult } \\
\text { Locations }\end{array}$ & body cavities & subcutaneous tissues & subcutaneous tissues \\
\hline $\begin{array}{l}\text { Common } \\
\text { Microfilarial } \\
\text { Locations }\end{array}$ & blood & skin & blood \\
\hline Diagnosis & peripheral blood smear & skin snip & blood smear \\
\hline $\begin{array}{l}\text { Recommended } \\
\text { Treatment }\end{array}$ & mebendazole & $\begin{array}{l}\text { DEC (diethylcarbamazine)/ } \\
\text { ivermectin }\end{array}$ & ivermectin \\
\hline $\begin{array}{l}\text { Geographic } \\
\text { Range }\end{array}$ & Africa and the Americas & West and central Africa & the Americas \\
\hline
\end{tabular}

\section{Results}

The goals of the systematic review were to identify the areas of the world where mansonelliasis has been studied, to identify the prevalence rate in affected communities, and to list the risk factors that have been identified for each species. These findings are presented below and in Tables 2, 3, and 4.

Mansonella perstans is found in both Africa and the Americas, but has primarily been studied in Africa (Table 2). The prevalence in endemic areas varies greatly even within small geographic regions. For example, a 2003 study of school children in Uganda showed variation in school-level prevalence ranging from $0.4 \%$ to $72.8 \%$ (Onapa et al., 2005), and a 2005-2006 study in Uganda found a rate of $57.7 \%$ in one community and $76.5 \%$ in a neighboring community (Asio et al., 2009). Other studies from Uganda have found village prevalence rates as low as 2\% (Onapa et al., 2001) and 21\% (Hillier et al., 2008) and as high as 96\% (Fischer et al., 1997). A study in Cameroon found village prevalence rates ranging from 55\% to 100\% (Wanji et al., 2003), while another study from Cameroon found a lower prevalence rate of 26.6\% (Mommers et al., 1994). A study of villages in Congo found village rates ranging from $22.0 \%$ to $89.5 \%$ (Noireau et al., 1989) and a study in Burkina Faso found village rates ranging from 3.5\% to 14\% (Kyelem et al., 2003). Prevalence rates from other studies in West and Central Africa demonstrate a similarly wide infection rate, ranging from $3.2 \%$ to $47 \%$ in Nigeria (Agbolade and Akinboye, 2001; Akogun, 1992; Anosike et al., 1992, 2005b; Arene and Atu, 1986; Udonsi, 1986, 1988; Ufomadu et al., 1991; Useh and Ejezie, 1995) and 6.0\% in Sierra Leone (Gbakima and Sahr, 1996) to $49.1 \%$ in Gabon (Van Hoegaerden et al., 1987), 66.3\% in Guinea (Vila Montlleo, 1990), and 75\% in Mali (Keiser et al., 2003). The only recent study from Latin America was conducted among an indigenous population in Venezuela and found a prevalence of 11.3\% (Gómez and Guerrero, 2000). A study from Colombia found a prevalence of $6 \%$ in affected communities in the 1980s (Kozek et al., 1983).

Co-infection with $M$. perstans and other filarial infections appears to be common. $42.3 \%$ of onchocerciasis patients in a study in Togo were co-infected with M. perstans (Schulz-Key et al., 1993), 36.9\% of participants in a study in Cameroon were infected with both M. perstans and O. volvulus (Wanji et al., 2003), $14 \%$ of participants in a study in Gabon had both M. perstans and L. loa (Van Hoegaerden et al., 1987), 10.1\% of persons with $M$. perstans infection in a study from Nigeria also had L. loa (Ufomadu et al., 1991), and 9\% of participants in a study conducted in the Congo were infected with both M. perstans and L. loa and 7\% had both 
M. perstans and M. streptocerca (Noireau et al., 1989). Given the concern that has been raised about filarial coinfection with other agents, this may be an area of concern (Boussinesq et al., 2003; Gardon et al., 1997).

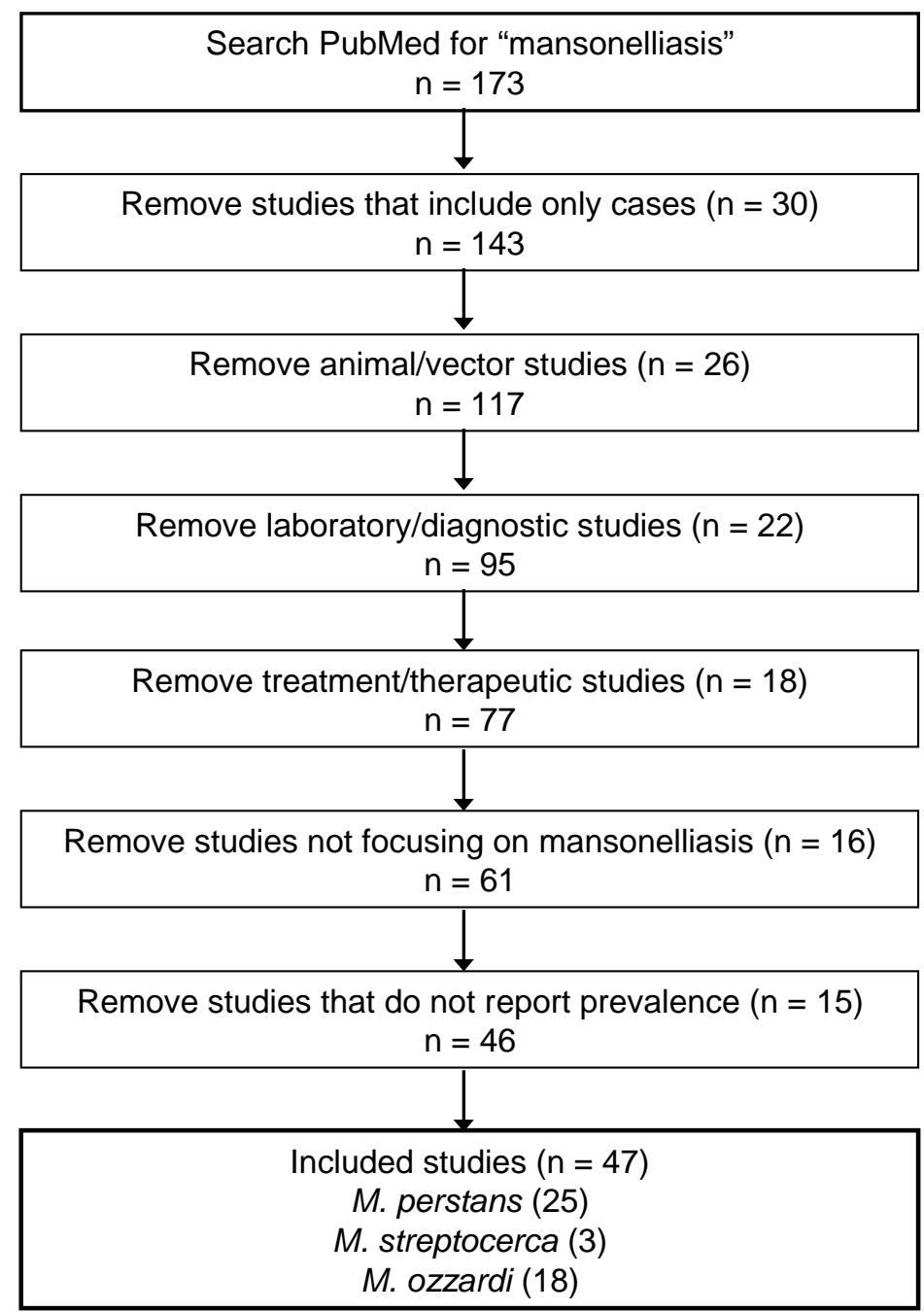

Figure 1: Search strategy.

Most studies that examined differences in $M$. perstans prevalence by sex found no difference between males and females (Agbolade et al., 2001; Asio et al., 2009; Boussinesq et al., 2003; Gbakima and Sahr, 1996; Ufomadu et al., 1991; Useh et al., 1995) although several other studies observed a higher rate in males than females (Anosike et al., 2005b; Mommers et al., 1994; Noireau et al., 1989; Wanji et al., 2003). Studies of the association between age and infection consistently found a higher rate in adults than children (Agbolade et al., 2001; Anosike et al., 2005b; Asio et al., 2009; Gbakima and Sahr, 1996; Keiser et al., 2003; Mommers et al., 1994; Noireau et al., 1989; Ufomadu et al., 1991; Wanji et al., 2003).

Mansonella streptocerca occurs in west and central Africa, and has been the focus of relatively few studies (Table 3). As was found for M. perstans, the prevalence rate appears to vary widely within endemic areas. A study in western Uganda in the mid-1990s found that the village prevalence ranged from $5 \%$ to $89 \%$ (Fischer et al., 1997). A study from the 1980s conducted in the Central African Republic found a prevalence of $13.5 \%$ (Okelo et al., 1988) and a study in Nigeria from the early 1990 s found a prevalence of $0.5 \%$ (Anosike and Onwuliri, 1994). Additional studies are required to establish the geographic range where this agent is endemic and to identify risk factors. 
Table 2. Epidemiological studies of M. perstans.

\begin{tabular}{|c|c|c|c|c|c|}
\hline Country & Study Year & Sample Size & $\begin{array}{l}\text { Age Range } \\
\text { (years) }\end{array}$ & Prevalence & Reference \\
\hline Colombia & -- & 604 & -- & $6 \%$ & Kozek, 1983 \\
\hline Burkina Faso & 2001 & 3303 & $\geq 1$ & $6 \%$ & Kyelem, 2003 \\
\hline \multirow{2}{*}{ Cameroon } & 1992 & 466 & $\geq 0.5$ & $27 \%$ & Mommers, 1994 \\
\hline & -- & 1458 & $\geq 15$ & $70 \%$ & Wanji, 2003 \\
\hline Congo & 1985-1986 & 2313 & $\geq 1$ & $29 \%$ & Noireau, 1989 \\
\hline Gabon & 1984-1985 & 411 & $9-70$ & $49 \%$ & Van Hoegaerden, 1987 \\
\hline Guinea & 1989 & 829 & $\geq 10$ & $66 \%$ & Vila Montlleo, 1990 \\
\hline Mali & -- & 40 & $18-65$ & $75 \%$ & Keiser, 2003 \\
\hline \multirow{10}{*}{ Nigeria } & $2003-2004$ & 373 & -- & $3 \%$ & Anosike, 2005a \\
\hline & $1996-2000$ & 755 & $\geq 5$ & $9 \%$ & Anosike, 2005b \\
\hline & 1997-1998 & 373 & $4-55$ & $3 \%$ & Agbolade, 2001 \\
\hline & 1988-1991 & 4183 & $0-70$ & $29 \%$ & Anosike, 1992 \\
\hline & 1993 & 840 & $\geq 1$ & $15 \%$ & Useh, 1995 \\
\hline & 1989 & 2552 & -- & $11 \%$ & Akogun, 1992 \\
\hline & 1984-1987 & 940 & $3-80$ & $8 \%$ & Ufomadu, 1990 \\
\hline & -- & 845 & -- & $13 \%$ & Udonsi, 1988 \\
\hline & 1983-1984 & 1674 & $\geq 1$ & $47 \%$ & Arene, 1986 \\
\hline & -- & 1351 & $\geq 1$ & $46 \%$ & Udonsi, 1986 \\
\hline Sierra Leone & 1993 & 630 & $5-70$ & $6 \%$ & Gbakima, 1996 \\
\hline Togo & -- & 182 & -- & $42 \%$ & Schulz-Key, 1993 \\
\hline \multirow{6}{*}{ Uganda } & $2005-2006$ & 1566 & $\geq 1$ & $65 \%$ & Asio, 2009 \\
\hline & $2003-2005$ & 2499 & $14-47$ & $21 \%$ & Hillier, 2008 \\
\hline & 2003 & 12207 & $5-19$ & $61 \%$ & Onapa, 2005 \\
\hline & 1998 & 3548 & -- & & Onapa, 2001 \\
\hline & 1994-1995 & 233 & $\geq 14$ & $96 \%$ & Fischer, 1997a \\
\hline & 1991-1993 & 1543 & $\geq 14$ & $49 \%$ & Fischer, 1996 \\
\hline
\end{tabular}

--: information not provided in article

Table 3: Epidemiological studies of $M$. streptocerca.

\begin{tabular}{llllll}
\hline Country & Study Year & Sample Size & $\begin{array}{l}\text { Age Range } \\
\text { (years) }\end{array}$ & Prevalence & Reference \\
\hline $\begin{array}{l}\text { Central African } \\
\text { Republic }\end{array}$ & -- & 267 & $1-100$ & $14 \%$ & Okelo, 1988 \\
\hline Nigeria & $1990-1992$ & 1349 & $0-70$ & $0.5 \%$ & Anosike, 1994 \\
\hline Uganda & $1994-1995$ & 806 & $\geq 14$ & $61 \%$ & Fischer, 1997a \\
\hline
\end{tabular}

--: information not provided in article

Mansonella ozzardi infection, also known as mansonellosis, occurs only in the Americas (Table 4). In the past ten years, the results of cross-sectional studies from Brazil (Cohen et al., 2008; Garrido and Campos, 2000; Medeiros et al., 2008), Bolivia (Bartoloni et al., 1999), and Venezuela (Gómez and Guerrero, 2000) have been published. Most of the studies in Brazil and Venezuela were conducted in communities located along rivers in the Amazon basin and focused on indigenous groups. The prevalence rates ranged from 9.9\% (Gómez and Guerrero, 2000) to $18.9 \%$ (Cohen et al., 2008) to 28.2 \% (Garrido and Campos, 2000) to 30.2\% (Medeiros et al., 2008). Older studies from Brazil found prevalence rates ranging from 4\% (Shelley, 1975) to 27\% (Lage, 1964). The Bolivian study also focused primarily on an indigenous population, and found a total prevalence of $0.7 \%$ in one town and $26 \%$ in a neighboring town of $26 \%$ (Bartoloni et al., 1999), which suggests the same diverse range of prevalence rates found for the other species. Prevalence rates from studies of rural areas in Venezuela ranged from 11\% (Beaver et al., 1976) to 22\% (Le Bras et al., 1978) to 30\% (Formica and Botto, 1990 ) to $36 \%$ (Medrano et al., 1992) to 58\% (Godoy et al., 1980). In a study from the 1970s, about $16 \%$ (Raccurt et al., 1980) of inhabitants surveyed from Bayeux, Haiti, were found to be infected with Mansonella ozzardi. In Colombia, prevalence rates ranged from 3\% (Kozek et al., 1984) to 13\% (Kozek et al., 1983) to 49\% (Lightner et al., 1980). These studies consistently found that risk of infection increased with age (Bartoloni et al., 1999; Le Bras et al., 1978; Medeiros et al., 2008; Nathan et al., 1979). Although one study from Trinidad in 
the 1970s indicated an increased risk of infection in males (Nathan et al., 1979), more recent studies from Bolivia (Bartoloni et al., 1999) and Brazil (Medeiros et al., 2008) found no differences in prevalence by sex. Thus, aside from age no risk factors have been firmly established.

Table 4: Epidemiological studies of M. ozzardi.

\begin{tabular}{|c|c|c|c|c|c|}
\hline Country & Study Year & Sample Size & $\begin{array}{l}\text { Age Range } \\
\text { (years) }\end{array}$ & Prevalence & Reference \\
\hline Bolivia & 1997 & 594 & $0-85$ & $26 \%$ & Bartoloni, 1999 \\
\hline \multirow{5}{*}{ Brazil } & 2007 & 129 & $\geq 2$ & $30 \%$ & Mederios, 2008 \\
\hline & 2006 & 543 & -- & $19 \%$ & Cohen, 2008 \\
\hline & -- & 496 & -- & $28 \%$ & Garrido, 2000 \\
\hline & -- & 386 & -- & $4 \%$ & Shelley, 1975 \\
\hline & -- & 262 & -- & $27 \%$ & Lage, 1964 \\
\hline \multirow{3}{*}{ Colombia } & -- & 347 & $8-70$ & $49 \%$ & Lightner, 1980 \\
\hline & -- & 627 & -- & $3 \%$ & Kozek, 1984 \\
\hline & -- & 604 & -- & $13 \%$ & Kozek, 1983 \\
\hline Haiti & -- & 1165 & all & $16 \%$ & Raccurt, 1980 \\
\hline Mexico & 1956 & 329 & -- & $61 \%$ & Biagi, 1956 \\
\hline Trinidad & -- & 4,488 & $\geq 5$ & $5 \%$ & Nathan, 1979 \\
\hline \multirow{5}{*}{ Venezuela } & -- & 1057 & -- & $10 \%$ & Gomez, 2000 \\
\hline & 1983-1989 & 423 & -- & $36 \%$ & Medrano, 1992 \\
\hline & -- & 139 & -- & $58 \%$ & Godoy, 1980 \\
\hline & 1977 & 146 & $\geq 6$ & $22 \%$ & Le Bras, 1978 \\
\hline & -- & 187 & -- & $10 \%$ & Beaver, 1976 \\
\hline
\end{tabular}

--: information not provided in article

\section{Discussion}

While the three agents that cause mansonelliasis share these similarities, they are distinct infections with unique agent, clinical, and epidemiological characteristics. Although infection is usually asymptomatic, millions of people worldwide - especially those in rural areas - are at risk. This systematic review shows that mansonelliasis may be a common infection in parts of Latin American and west and central Africa, with significant variation in prevalence rates over small geographic spaces, but the review also highlights the lack of current information about the prevalence of mansonelliasis in most areas likely to at risk. Also, although the review indicates that the risk of infection increases with age and may be higher in males than females, there is a need for additional work to identify specific demographic and environmental risk factors. Updated information will be important for making differential diagnoses in endemic and epidemic areas, promoting measures to control vectors in areas with significant burden from the disease, identifying the possible risks of co-infection with multiple filariases, and addressing the concerns of at-risk populations.

\section{References}

1. Agbolade OM, Akinboye DO. (2001). Loa loa and Mansonella perstans infections in Ijebu North, Western Nigeria: a parasitological study. Japan J Infect Dis, 54: 108-110.

2. Akogun OB. (1992). Filariasis in Gongola State Nigeria. 1. Clinical and parasitological studies in Mutum-Biyu District. Angew Parasitol, 33: 125-131.

3. Anosike JC, Nwoke BEB, Onwuliri COE, Obiukwu CE, Duru AF, Nwachukwu MI, Ukaga CN, Uwaezuoke JC, Uduji OS, Amajuoyi OU, Nkem BI. (2005a). Prevalence of parasitic diseases among nomadic Fulanis of south-eastern Nigeria. Ann Agric Environ Med, 11: 221-225.

4. Anosike JC, Dozie INS, Onwuliri COE, Nwoke BEB, Onwuliri VA. (2005b). Prevalence of Mansonella perstans infections among the nomadic Fulanis of northern Nigeria. Ann Agric Environ Med, 12: 35-39.

5. Anosike JC, Onwuliri CO, Payne UK, Amuta EU, Akogun OB, Adeiyongo CM, Nwoke BE. (1992). Observations on mansonellosis among the Ibos of Abia and and Imo States, Nigeria. Angew Parasitol, 33: 235-241.

6. Anosike JC, Onwuliri CO. (1994). Studies on filariasis in Bauchi State, Nigeria. II. The prevalence of human filariasis in Darazo Local Government area. Appl Parasitol , 35: 242-250.

7. Arene FO, Atu FN. (1986). Mansonella perstans microfilaraemia among the Bori community in the Niger Delta area of Nigeria. Ann Trop Med Parasitol , 80: 535-536. 
8. Asio SM, Simonsen PE, Onapa AW. (2009). Mansonella perstans filariasis in Uganda: patterns of microfilaraemia and clinical manifestations in two endemic communities. Trans R Soc Trop Med Hyg, 103: 266-273.

9. Barry M. (2007). The tail end of Guinea worm: global eradication without a drug or a vaccine. N Engl J Med , 356: 2561-2564.

10. Bartoloni A, Cancrini G, Bartalesi F, Marcolin D, Roselli M, Arce CC, Hall AJ. (1999). Mansonella ozzardi infection in Bolivia: prevalence and clinical associations in the Chaco region. Am J Trop Med Hyg , 61: 830833.

11. Beaver PC, Neel JV, Orihel TC. (1976). Dipetalonema perstans and Mansonella ozzardi in Indians of southern Venezuela. Am J Trop Med Hyg, 25: 263-265.

12. Biagi F. (1956). Observations on mansonelliasis in the Peninsula of Yucatan. I. Frequency. Medicina (Mex), 36:521-526.

13. Black WC, Freier JE, Hagedorn HH, Hemingway J, Higgs S, James A, Kondratieff B, Moore CG. (2004). Biology of Disease Vectors. $2^{\text {nd }}$ ed. London, UK: Elsevier Academic Press.

14. Boussinesq M, Gardon J, Gardon-Wendel N, Chippaux, JP. (2003). Clinical picture, epidemiology and outcome of Loa-associated serious adverse events related to mass invermectin treatment of onchocerciasis in Cameroon. Filaria J, 2(Suppl 1): S4.

15. Bregani ER, Balzarini L, Mbaïdoum N, Rovellini A. (2007). Prevalence of filariasis in symptomatic patients in Moyen Chari district, south of Chad. Trop Doct, 37: 175-177.

16. Bregani ER, Rovellini A, Mbaidoum, Magnini MG. (2006). Comparison of different anthelminthic drug regimens against Mansonella perstans filariasis. Trans R Soc Trop Med Hyg, 100: 458-463.

17. Cairncross S, Muller R, Zagaria N. (2002). Dracunculiasis (Guinea worm disease) and the eradication initiative. Clin Microbiol Rev, 15: 223-246.

18. Centers for Disease Control and Prevention (2008). DPDX: laboratory identification of parasites of public health concern. US Centers for Disease Control and Prevention. http://www.dpd.cdc.gov/dpdx [accessed August 20, 2008].

19. Cohen JM, Santana Ribeiro JA, Martins M. (2008). Acometimento ocular em pacientes com mansonelose. Arq Bras Oftalmol , 71: 167-171.

20. Fischer P, Bamuhiiga J, Büttner DW. (1997). Occurrence and diagnosis of Mansonella streptocerca in Uganda. Acta Tropica, 63: 43-55.

21. Fischer P, Kilian AH, Bamuhilgu J, Kipp W, Büttner DW. (1996). Prevalence of Mansonella perstans in western Uganda and its detection using the QBC-fluorescence method. Appl Parasitol , 37:32-37.

22. Formica S, Botto C. (1990). Filariasis focus due to Mansonella ozzardi and Mansonella perstans in the Amazon Federal Territory of Venezuela. J Trop Med Hyg , 84: 160-165.

23. Garcia L. (2007). Diagnostic Medical Parasitology. $5^{\text {th }}$ ed. Washington, DC: American Society for Microbiology.

24. Gardon J, Gardon-Wendel N, Demanga-Ngangue, Kamgno J, Chippaux JP, Boussinesq M. (1997). Serious reactions after mass treatment of onchocerciasis with invermectin in an area endemic for Loa loa infection. Lancet, 350: 18-22.

25. Garrido C, Campos M. (2000). First report of presumed parasitic keratitis in Indians from the Brazilian Amazon. Cornea, 19: 817-819.

26. Gbakima AA, Sahr F. (1996). Filariasis in the Kaiyamba Chiefdom, Moyamba District Sierra Leone: an epidemiological and clinical study. Public Health, 110: 169-174.

27. Godoy GA, Volcan G, Medrano C, Teixeira A, Matheus L. (1980). Mansonella ozzardi infections in Indians of the southwestern part of the state of Bolivar, Venezuela. Am J Trop Med Hyg, 29: 373-376.

28. Gómez J, Guerrero R. (2000). Environmental factors and the distribution of mansonelliases in southern Venezuela. Parasite, 7: 71-76.

29. Heymann D, editor. (2004). Control of Communicable Disease Manual, $18^{\text {th }}$ ed. Washington, D.C: APHA.

30. Hillier SD, Booth M, Muhangi L, Nkurunziza P, Khihembo M, Kakande M, Sewankambo M, Kizindo R, Kizza M, Muwanga M, Elliott AM. (2008). Plasmodium falciparum and helminth coinfection in a semi urban population of pregnant women in Uganda. J Infect Dis , 198: 920-927.

31. Keiser PB, Coulibaly YI, Keita F, Traore D, Diallo A, Dialla DA, Semnani RT, Doumbo OK, Traore SF, Klion AD, Nutman TB. (2003). Clinical characteristics of post-treatment reactions to ivermectin / albendazole for Wuchereria bancrofti in a region co-endemic for Mansonella perstans. Am J Trop Med Hyg, 69: 331-335.

32. Kozek WJ, Palma G, Henao A, García H, Hoyos M. (1983). Filariasis in Colombia: prevalence and distribution of Mansonella ozzardi and Mansonella (=Dipetalonema) perstans infections in the Comisaría del Guainía. Am J Trop Med Hyg , 32: 379-84.

33. Kozek WJ, Palma G, Valencia W, Montalvo C, Spain J. (1984). Filariasis in Colombia: prevalence of Mansonella ozzardi in the Department de Meta, Intendencia del Casanare, and Comisaria del Vichada. Am J Trop Med Hyg, 33: 70-72.

34. Kyelem D, Sanou S, Boatin B, Medlock J, Coulibaly S, Molyneux DH. (2003). Impact of long-term ivermectin (Mectizan) on Wuchereria bancrofti and Mansonella perstans infections in Burkina Faso: strategic and policy implications. Ann Trop Med Parasitol , 8: 827-838. 
35. Lage HA. (1964). Mansonelliasis in Indians of the Aruak group of the I Cana River Region. Hospital (Rio J), 66: $557-564$.

36. Le Bras J, Fonval F, Solal C. (1978). Paludisme, eosinophilie et filarioses chez les Indians Cuiva du Venezuela. Med Mal Infect, 6: 274-278.

37. Lightner LK, Ewert A, Corredor A, Sabogal E. (1980). A parasitologic survey for Mansonella ozzardi in the Comisaria del Vaupes, Colombia. Am J Trop Med Hyg, 29:42-45.

38. Medeiros JF, Py-Daniel V, Barbosa UC, Ogawa GM. (2008). Current profile of Mansonella ozzardi (Nematode: Onchocercidae) in communities along the Ituxi river, Lábrea municipality, Amazonas, Brazil. Mem Inst Oswaldo Cruz, 103: 409-411.

39. Medrano CE, Volcan GS, Godoy GA. (1992). Mansonelliasis in the southeast Venezuelan Orinoquia region. Rev Inst Med Trop Sao Paula, 34: 61-70.

40. Mommers EC, Dekker HS, Richard P, Garcia A, Chippaux JP. (1994). Prevalence of L. loa and M. perstans filariasis in southern Cameroon. Trop Geogr Med, 47: 2-5.

41. Nathan MB, Tikasingh ES, Nelson GS, Santiago A, Davies JB. (1979). The prevalence and distribution of Mansonella ozzardi in coastal north Trinidad, W.I. Trans R Soc Trop Med, 73: 299-302.

42. Noireau F, Carme B, Apembet JD, Gouteux JP. (1989). Loa loa and Mansonella perstans filariasis in the Chaillu mountains, Congo: parasitological prevalence. Trans R Soc Trop Med Hyg, 83: 529-534.

43. Okelo GB, Kyobe J, Gatiri. (1988). Mansonella streptocerca in the Central African Republic. Trans R Soc Trop Med Hyg, 82: 464.

44. Onapa AW, Simonsen PE, Pedersen EM, Okello DO. (2001). Lymphatic filariasis in Uganda: baseline investigations in Lira, Soroti and Katakwi districts. Trans R Soc Trop Med Hyg , 95: 161-167.

45. Onapa AW, Simonsen PE, Baeher I, Pederson EM. (2005). Mansonella perstans infections in Uganda, by screening schoolchildren for microfilariae. Ann Trop Med Parasitol , 99: 383-393.

46. Raccurt C, Lowrie RC Jr. McNeeley DF. (1980). Mansonella ozzardi in Haiti. 1. Epidemiological survey. Am J Trop Med Hyg, 28: 803-808.

47. Schulz-Key H, Albrecht W, Heuschkel C, Soboslay PT, Banla M, Görgen H. (1993). Efficacy of ivermectin in the treatment of concomitant Mansonella perstans infections in onchocerciasis patients. Trans $\mathrm{R}$ Soc Trop Med Hyg , 87: 227-229.

48. Service M. (2004). Medical entomology for students. $3^{\text {rd }}$ edition. London: Cambridge University Press.

49. Shelley AJ, Coscarón, S. (2001). Simuliid Blackflies (Diptera: Simuliidae) and Ceratopogonid Midges (Diptera: Ceratopogonidae) as vectors of Mansonella ozzardi (Nematode: Onchocercidae) in Northern Argentina. Mem Inst Oswaldo, 96: 451-458.

50. Shelley AJ. (1975). A preliminary survey of the prevalence of Mansonella ozzardi in some rural communities on the river Purus, state of Amazonas, Brazil. Ann Trop Med Parasitol , 69: 407-412.

51. Udonsi JK. (1988). Filariasis in the Igwun River Basin, Nigeria: an epidemiological and clinical study with a note on the vectors. Ann Trop Med Parasitol , 82: 75-82.

52. Udonsi JK. (1986). The status of human filariasis in relation to clinical signs in endemic areas of the Niger Delta. Ann Trop Med Parasitol, 80: 425-432.

53. Ufomadu GO, Nwoke BEB, Akoh JI, Sato Y, Ekejindu GOC, Uchida A, Shiwaku K, Tumbau M, Ugomo KK. (1991). The occurrence of loiasis, mansonellosis and wuchereriasis in the Jarawa River Valley, Central Nigeria. Acta Tropica, 48: 137-147.

54. Useh MF, Ejezie GC. (1995). The status and consequences of Mansonella perstans infection in Calabar, Nigeria. East Afr Med J, 72: 124-126.

55. Van Hoegaerden M, Chabaud B, Akue JP, Ivanoff B. (1987). Filariasis due to Loa loa and Mansonella perstans: distribution in the region of Okondja, Haut-Ogooué Province, Gabon, with parasitological and serological follow-up over one year. Trans R Soc Trop Med Hyg, 81: 441-446.

56. Vila Montlleo R. (1990). Filariose sanguine due a Loa-loa et a Mansonella perstans dans la partie continentale de la guinee equatoriale. Resulats prealables. Med Trop (Mars), 50: 399-402.

57. Wanji S, Tendongfor N, Esum M, Ndindeng S, Enyong P. (2003). Epidemiology of concomitant infections due to Loa loa, Mansonella perstans, and Onchocerca volvulus in rain forest villages of Cameroon. Med Microbiol Immunol , 192: 15-21. 